THE ALL-RUSSIAN CONGRESS OF ZOOLOGISTS IN PETROGRAD

The first All-Russion Congress of Zoologists, Anatomists and Histologists is to be convened from April 23 to April 30 in Petrograd. At this congress it is expected to have the following sections: 1. Systematics, Zoogeography and Ecology; 2. Morphology (with Embryology) ; 3. Anatomy and Histology; 4. Experimental Zoology and Genetics. For the general sessions of the congress the following addresses will be delivered:

L. S. Berg: Polyphiletism and evolution.

A. S. Dogel: The causes which lead the living body to old age and death.

G. A. Kojevnikoff: Polymorphism and evolution.

N. K. Koltzoff: Eugenies, its problems and methods.

N. M. Koulagin: Zoology, science and agriculture.

M. M. Novikoff: Modern opinion regarding structure of chambers.

A. N. Severtzoff: The origin of fish and problems of phylogeny connected with this question.

P. P. Soushkin: The history of fauna of Siberia and Central Asia.

U. A. Philipehenko: The problem of experimental study of variations.

T.M. Shimkevich: About the regularity of the systematical indications.

V. M. Shimkevich is chairman and $\mathrm{K}$. Derugin and $\mathrm{V}$. Tonkoff are vice-chairmen.

\section{ASSOCIATION OF GEOLOGISTS AND NATURALISTS IN PEKING AND VICINITY}

THERE has recently been effected an informal association in Peking to bring together the geologists and naturalists resident in Peking and the vicinity for discussion of problems of mutual interest and the furtherance of intellectual intercourse among men of science in the Far East. Several meetings have been held at the residence of Dr. Roy Chapman Andrews at the headquarters of the Third Asiatic Expedition, at the residence of Dr. J. G. Anderson, at the Peking Hotel, in Central Park and elsewhere. The meetings are preceded by an informal dinner. On March 22 Dr. Walter Granger was expected to present the results of his recent expedition to the fossil fields of eastern Szechman province.

Those who have previously attended these meetings include:

Dr. V. K. Ting, honorary director of the Geological Survey of China.

Dr. W. H. Wong, director Geological Survey of China.

Dr. J. G. Andersson, mining adviser to the Chinese government.

Dr. E. E. Ahnert, director Geological Committee of the Russian Far East, Vladivostock.

Dr. Roy Chapman Andrews, director of the Third Asiatic Expedition.

Professor George B. Barbour, professor of geology, Pei Yang University, Tientsin.

Dr. Davidson Black, director of the department of anatomy, Peking Union Medical College.

Dr. Walter Granger, paleontologist to the Third Asiatic Expedition.

Dr. Otto Zdansky, associate paleontologist to the Geologieal Survey, China.

Professor Charles P. Berkey, geologist of the Third Asiatic Expedition.

Mr. Clifford Pope, assistant zoologist of the Third Asiatic Expedition.

Dr. F. R. Tegrengen, mining geologist.

Professor F. K. Morris, associate geologist of the Third Asiatic Expedition.

Dr. A. W. Grabau, paleontologist of the Geological Survey of China and professor of paleontology, National University, Peking.

Dr. Harry Smith, assistant professor of botany, Uppsala, botanist and explorer.

Père Licent, naturalist and explorer, Tientsin.

The gatherings are said to have proved highly stimulating. Frequent meetings during the winter and spring months are planned.

\section{THE MENDEL CENTENNIAL}

IN commemoration of the hundredth anniversary of the birth of Gregor Mendel, there will be held a scientific gathering in the city of Brünn, Czechoslovakia, from September 22 to 24. A Festchrift containing original contributions in the field of genetics will be published.

The secretary of the local committee, Professor Dr. Hugo Iltis, has asked me to call this celebration to the attention of American geneticists and to extend to them a cordial invitation to take part in the celebration in any or all of the following ways: 
(1) By accepting membership on the International Committee: (2) by being present in person at the gathering in Brünn on the date mentioned; (3) by making a voluntary contribution toward the expenses of the gathering and of the Festschrift; and (4) by submitting a manuscript for publication in the memorial volume. Such MSS. should be sent to Professor Dr. Hugo Iltis, Bäkergasse 10, Brünn, Czechoslovakia, and should be in his hands by the end of May, 1922. Money contributions should be made payable to the MendelfeierKonto, Böhmische Eskompte-u. Kreditbank, Brünn. It is hoped that American geneticists will cooperate as fully as possible to make the celebration a success.

\section{Geo. H. ShuLL}

\section{COLLOID CHEMISTRY AT THE UNIVERSITY OF WISCONSIN}

THE chemistry department of the University of Wisconsin announces that Professor The. Svedberg, of the University of Uppsala, will be in residence during the second semester of the scholastic year of 1922-23 and the summer session of 1923.

While at Wisconsin, Professor Svedberg will organize and direct the research work in colloid chemistry, and will also give two lectures each week on the subject and conduct two weekly seminaries. One seminary will be devoted to the broader aspects of colloid chemistry and the other to its biological applications.

Professor Svedberg is recognized as one of the international authorities on the subject of colloid chemistry. He is the author of many papers dealing with the fundamental principles of colloid chemistry and has written the best known treatises on the preparation of colloids. His work has been recognized by the award of numerous prizes and special research funds and he has been honored by numerous foreign societies.

During the summer session of 1923, lasting for a period of six weeks, the lectures given during the second semester will be repeated for the benefit of educators and research workers who find it impossible to attend the university during the regular session. A seminary will also be conducted throughout the summer session.
Advanced workers who desire to do work under the direction of Professor Svedberg should communicate with Professor J. H. Mathews, director of the course in chemistry, since only a limited number of research workers can be accommodated.

\section{YALE UNIVERSITY AND DR. CHITTENDEN}

$A T$ the regular monthly meeting of the Yale Corporation, held on March 11, the following resolution was adopted in connection with the resignation of Dr. Chittenden as director of the Sheffield Scientific School, which takes effect at the close of the present university year:

Even in his undergraduate days in the Sheffield Scientific School Director Chittenden had begun to pave the way to a distinguished eareer as a teacher and investigator in physiological chemistry, for the development of whịch as an independent branch of study he has been responsible not only at Yale but in large measure in the United States. His was in many respects the path of a pioneer in a borderline science which inevitably led both at home and abroad to recognition and honors in which the institution that Director Chittenden served has shared abundantly.

Not less successful has been Dr. Chittenden's leadership as director of the Sheffield Scientific School for nearly a quarter of a century. His unflagging energy and broad vision have contributed largely to increase the material resources of the school, to enlarge the scope of its usefulness as an institution for professional training in science, and to stimulate and encourage investigation. The recognition at Yale of the important part which the study of science should play in modern education is due in no small degree to Dr. Chittenden's influence. Research at Yale has always found a staunch supporter and advocate in him.

To a man of Dr. Chittenden's training and ideals even the partial abandonment of the pursuit of science necessitated by the call to an executive post must have meant a personal sacrifice. He has accepted this, as he has undertaken many other public tasks, in a spirit of service which deserves grateful recognition on the part of Yale Universiy.

The Yale Alumni Weelkly says in an editorial article:

The resolutions adopted on the resignation of Director Chittenden by the Yale Corporation place a richly merited emphasis on the eharacter 